\title{
rAAV-mediated overexpression of TGF- $\beta$ stably restructures human osteoarthritic articular cartilage in situ
}

Jagadeesh K Venkatesan ${ }^{1 \dagger}$, Ana Rey-Rico ${ }^{1 \dagger}$, Gertrud Schmitt', Anna Wezel ${ }^{1}$, Henning Madry ${ }^{1,2}$ and Magali Cucchiarini ${ }^{1 *}$

\begin{abstract}
Background: Therapeutic gene transfer is of significant value to elaborate efficient, durable treatments against human osteoarthritis $(\mathrm{OA})$, a slow, progressive, and irreversible disorder for which there is no cure to date.

Methods: Here, we directly applied a recombinant adeno-associated virus (rAAV) vector carrying a human transforming growth factor beta (TGF- $\beta$ ) gene sequence to primary human normal and OA chondrocytes in vitro and cartilage explants in situ to monitor the stability of transgene expression and the effects of the candidate pleiotropic factor upon the regenerative cellular activities over time.

Results: Efficient, prolonged expression of TGF- $\beta$ achieved via rAAV gene transfer enhanced both the proliferative, survival, and anabolic activities of cells over extended periods of time in all the systems evaluated (at least for 21 days in vitro and for up to 90 days in situ) compared with control (reporter) vector delivery, especially in situ where rAAV-hTGF- $\beta$ allowed for a durable remodeling of OA cartilage. Notably, sustained rAAV production of TGF- $\beta$ in OA cartilage advantageously reduced the expression of key OA-associated markers of chondrocyte hypertrophic and terminal differentiation (type-X collagen, MMP-13, PTHrP, $\beta$-catenin) while increasing that of protective TIMPs and of the TGF- $\beta$ receptor I in a manner that restored a favorable ALK1/ALK5 balance. Of note, the levels of activities in TGF- $\beta$-treated OA cartilage were higher than those of normal cartilage, suggesting that further optimization of the candidate treatment (dose, duration, localization, presence of modulating co-factors) will most likely be necessary to reproduce an original cartilage surface in relevant models of experimental OA in vivo without triggering potentially adverse effects.

Conclusions: The present findings show the ability of rAAV-mediated TGF- $\beta$ gene transfer to directly remodel human OA cartilage by activating the biological, reparative activities and by regulating hypertrophy and terminal differentiation in damaged chondrocytes as a potential treatment for OA or for other disorders of the cartilage that may require transplantation of engineered cells.
\end{abstract}

Keywords: Human osteoarthritis, Articular cartilage, rAAV gene transfer, TGF- $\beta$

\section{Introduction}

Osteoarthritis (OA) is a major, widespread degenerative disease of the entire joint characterized by complex structural and functional tissue and cell alterations [1-5] for which there is no cure to date. OA has a multifactorial etiology, being influenced by both genetic, mechanical, and environmental factors [6-8]. The gradual and

\footnotetext{
* Correspondence: mmcucchiarini@hotmail.com

${ }^{\dagger}$ Equal contributors

${ }^{1}$ Center of Experimental Orthopaedics, Saarland University Medical Center, Kirrbergerstr. Bldg 37, Homburg/Saar 66421, Germany

Full list of author information is available at the end of the article
}

irreversible degradation of the articular cartilage in OA, associated with a remodeling of the subchondral bone and osteophyte formation, is the result of an impaired cartilage homeostasis (prevalence of catabolic events activated by biomechanical and pro-inflammatory mediators, failure of the chondrocytes to preserve and restore the metabolic balance) $[9,10]$. Thus far, none of the pharmacological treatments and surgical options available to manage OA have allowed to reproduce the original cartilage integrity in patients. The design of new therapeutic approaches for $\mathrm{OA}$ is therefore of crucial

\section{Biomed Central}

(c) 2013 Venkatesan et al.; licensee BioMed Central Ltd. This is an Open Access article distributed under the terms of the Creative Commons Attribution License (http://creativecommons.org/licenses/by/2.0), which permits unrestricted use, distribution, and reproduction in any medium, provided the original work is properly cited. 
importance to effectively and durably counteract the regular progression of the disease by activating regenerative processes in the chondrocytes as a means to re-equilibrate the disturbed cartilage balance.

Therapeutic gene transfer is a valuable tool to achieve this goal as it has the potential to allow for the production of factors over extended periods of time compared with the application of recombinant molecules with short pharmacological half-lives. While protection against cartilage breakdown was afforded by delivering sequences coding for agents with preventive and/or inhibitory activities (an IL-1 receptor antagonist - IL-1Ra, siRNAs against IL-1 or ADAMTS-5, soluble IL-1 and TNF receptors - sIL-1R and sTNFR, NF- $\mathrm{KB}$ inhibitors, kallistatin - KBP, thrombospontin-1 - TSP-1, Dickkopf-1 - DKK-1, pro-opiomelanocortin - POMC) [11-21], compensation for the loss of matrix elements and cells was not achieved to further re-establish an original cartilage surface in these various experimental systems. Instead, such effects have been ascribed, at least to some extent, to gene transfer of factors with anabolic and/or proliferative properties like proteoglycan 4 [22], the insulin-like growth factor I (IGF-I) $[18,23,24]$, fibroblast growth factor 2 (FGF-2) $[25,26]$, bone morphogenetic proteins 2 and 4 (BMP-2, -4 ) $[23,27]$, and the transcription factor SOX9 $[28,29]$.

Yet, even in the presence of such agents, only partial cartilage resurfacing was noted, showing the need to identify other components of therapeutic value for improved gene transfer applications in OA. Equally important, the development of an effective treatment for OA will necessitate that the gene vehicle promotes the stable expression of a candidate sequence that can durably counteracts the slow and irreversible progression of the disease. In this regard, the transforming growth factor beta (TGF- $\beta$ ) is an attractive candidate owing to its prominent, pleiotropic effects upon cartilage formation, chondrocyte proliferation, and extracellular matrix (ECM) synthesis and to its ability to suppress IL-1-induced cartilage breakdown [30-33]. Yet, little is known on the effects of TGF- $\beta$ gene transfer and overexpression in primary human OA articular chondrocytes and articular cartilage over relevant, extended periods of time. Most remarkably, Ulrich-Vinther et al. [34] reported that delivery of TGF- $\beta$ via the promising recombinant adeno-associated virus (rAAV) vectors resulted in increased levels of type-II collagen and aggrecan and reduced expression of matrix metalloproteinase 3 (MMP-3) in human OA chondrocytes in vitro for about a week although effects at later time points were not documented. As a matter of fact, rAAV are among the most advantageous classes of vectors available for therapy to date, especially for use as a gene transfer system in OA. rAAV derived from a human non-pathogenic replication-defective virus carry no viral coding sequences in the recombinant genome, making them less immunogenic than adenoviral vectors $[23,35,36]$. rAAV can modify the quiescent chondrocytes both in vitro and in situ in their dense ECM at very high efficiencies and for prolonged periods of time, probably due to their small size $(20 \mathrm{~nm})$ and to a good maintenance of the constructs in the host under episomal forms [24,26,28,34,37,38]. This is in marked contrast with nonviral [39] and adenoviral vectors $[23,35,36]$ that mediate only short-term transgene expression, and with retroviral vectors $[40,41]$ that require cell division and selection and carry the risk of insertional mutagenesis following integration in the host genome.

In the present study, we tested whether efficient TGF- $\beta$ overexpression can be achieved over prolonged periods of time via rAAV gene transfer in primary chondrocytes and explant cultures prepared from the articular cartilage of normal donors and OA patients (the ultimate targets for therapy), leading to enhanced levels of cell proliferation, survival, and matrix synthesis compared with control (reporter gene vector) treatment. We further analyzed the extent by which the candidate rAAV TGF- $\beta$ treatment is capable of restructuring OA cartilage compared with normal (control) cartilage and explored the pathways potentially implicated in the remodeling processes.

\section{Materials and methods \\ Reagents}

All reagents were from Sigma (Munich, Germany) except for the dimethylmethylene blue (DMMB) dye (Serva, Heidelberg, Germany). The anti-TGF- $\beta$ (V), anti-MMP13 (72B-01), anti-TIMP-1 (C-20) and -TIMP-3 (W-18), anti-parathyroid hormone-related protein (PTHrP) (1D1), anti- $\beta$-catenin (E-5), and anti-TGF- $\beta$ receptor I (activin receptor-like kinase-1 ALK1: C-20; ALK5: T-19) antibodies were from Santa Cruz Biotechnology (Heidelberg, Germany). The anti-type-II collagen (AF-5710) was antibody from Acris (Hiddenhausen, Germany). The anti-type$\mathrm{X}$ collagen (COL-10) and anti-BrdU (BU-33) antibodies were from Sigma. Active TGF- $\beta$ secretion was monitored with the hTGF- $\beta$ Quantikine ELISA (DB100B; R\&D Systems; Wiesbaden, Germany). The Cell Proliferation ELISA BrdU was from Roche Applied Science (Mannheim, Germany). The ApopTag ${ }^{\bullet}$ Plus Peroxidase In Situ Apoptosis Detection Kit was from Chemicon-Millipore (Schwal bach/Ts., Germany). The type-II collagen contents were measured with the native type-II collagen Arthrogen-CIA Capture ELISA kit (Chondrex, Redmond, WA, USA) and those for type-X collagen using a COL-10 ELISA (Antibodies-Online, Aachen, Germany).

\section{Cartilage and cells}

Human normal articular cartilage was obtained from unaffected knee joints removed during tumor surgery $(n=8$, age 65-73). OA was excluded on safranin O-stained 
sections using the Mankin score [42] (score 1-2). OA cartilage was obtained from joints undergoing total knee arthroplasty $(\mathrm{n}=14$, age 65-78) (Mankin score 7-9). The study was approved by the Ethics Committee of the Saarland Physicians Council. Research has been performed in accordance with the Declaration of Helsinki involving human material. Informed consent has been obtained from all participants. Explant cultures and chondrocytes (passage 1-2) were prepared as previously described $[24,26,28,38]$.

\section{Plasmids and rAAV vectors}

rAAV-lacZ is an AAV-2-based plasmid [43,44] carrying the $l a c Z$ gene encoding $\beta$-galactosidase under the control of the cytomegalovirus immediate-early (CMV-IE) promoter $[24,26,28,38]$. rAAV-hTGF- $\beta$ carries a 1.2-kb human transforming growth factor beta 1 (hTGF- $\beta$ ) cDNA fragment (intronless open reading frame from the ATG to the stop codon) (pORF9-hTGFB1) (Invivogen, Toulouse, France) that was cloned in $\mathrm{rAAV}-\mathrm{lacZ}$ in place of lacZ (the fragment was confirmed by sequencing). rAAV were packaged as conventional (not self-complementary) vectors using a helper-free, two-plasmid transfection system in the 293 cell line (an adenovirus-transformed human embryonic kidney cell line) using the packaging plasmid pXX2 and the Adenovirus helper plasmid pXX6 as previously described [45]. Vector preparations were purified by dialysis and titered by real-time PCR (about $10^{10}$ transgene copies/ml, with a ratio viral particles-to-functional vector of $500 / 1)[24,26,28,38]$.

\section{Gene transfer}

The vectors were applied to the samples based on concentrations previously tested [24,26,28]. Chondrocytes $\left(2 \times 10^{4}\right)$ were transduced with $\operatorname{rAAV}(40 \mu$ l, i.e. $8 \times$ $10^{5}$ functional recombinant viral particles; multiplicity of infection $\mathrm{MOI}=40$ ) and cultured for up to 21 days, while explant cultures were transduced by direct application of the vectors $(40 \mu \mathrm{l})$ onto the surface of the samples and cultured for up to 90 days $[24,26,28,38]$.

\section{Transgene expression}

Transgene (TGF- $\beta$ ) expression was monitored by indirect immunostaining using a specific antibody, a biotinylated secondary antibody (Vector Laboratories), and the ABC method (Vector Laboratories) using diaminobenzidine (DAB) as the chromogen. Samples were examined under light microscopy (Olympus BX 45; Hamburg, Germany) $[24,26,28,38]$. Expression of TGF- $\beta$ was also assayed by ELISA at the denoted time points (in vitro: days 5 and 21; in situ: days 21 and 90).

\section{Histological and immunohistochemical analyses}

Cell and explant cultures were fixed and explants were processed to stain paraffin-embedded sections $(5 \mu \mathrm{m})$ using safranin $\mathrm{O}$ to detect proteoglycans and hematoxylin eosin (H\&E) to detect cells [24,26,28]. Expression of typeII and type-X collagen, MMP-13, TIMP-1 and -3, PTHrP, $\beta$-catenin, and the TGF- $\beta$ receptor I (ALK1 and ALK5) was detected with specific antibodies, biotinylated secondary antibodies, and the ABC method with DAB. Samples were examined under light microscopy (Olympus BX 45).

\section{Cell proliferation and apoptosis assays}

The proliferative activities were assessed by immunolabeling after BrdU incorporation [24]. Briefly, BrdU was introduced at a final concentration of $3 \mu \mathrm{g} / \mathrm{ml}$ in the culture medium $24 \mathrm{~h}$ after rAAV transduction. Samples were immunochemically processed to monitor the proliferation rates with a specific anti-BrdU antibody, a biotinylated secondary antibody, and the ABC method with DAB. Proliferation was also assessed using the Cell Proliferation ELISA BrdU, with OD proportional to the cell numbers, as previously described [46]. In situ, nuclear DNA fragmentation consistent with apoptosis was determined by the terminal deoxynucleotidyl transferase-mediated dUTP nick end labeling (TUNEL) method $[24,26]$.

\section{Morphometric analyses}

The transduction efficiencies (ratio of cells positive for TGF- $\beta$ immunolabeling to the total number of cells on immunohistological sections), the cells positive for BrdU uptake (ratio of cells positive for BrdU immunolabeling to the total number of cells on immunohistological sections), the cell densities (cell numbers $/ \mathrm{mm}^{2}$ of surface of the site evaluated on histological sections), the apoptotic cells (ratio of cells positive for TUNEL assay to the total number of cells on immunohistological sections), the safranin $O$ staining intensities (ratio of tissue surface positively stained by safranin $O$ to the total surface of the site evaluated on histological sections), the type-II or type-X collagen immunostaining intensities (ratio of tissue surface positively immunostained by type-II or type-X collagen to the total surface of the site evaluated on immunohistological sections), as well as the cells positive for the expression of MMP-13, TIMP-1 and -3, PTHrP, $\beta$-catenin, and the TGF- $\beta$ receptor I (ALK1, ALK5, ALK1/ALK5 ratio) (ratio of cells positive for immunolabeling of each of these markers to the total number of cells on immunohistological sections) were measured at three random sites standardized for their surface or using ten serial histological and immunohistochemical sections for each parameter, test, and replicate condition to allow for calculation of standard deviations (SD). Analysis programs included SIS AnalySIS (Olympus), 
Adobe Photoshop (Adobe Systems, Unterschleissheim, Germany), and Scion Image (Scion Corporation, Frederick, MD, USA) [24,26,28].

\section{Biochemical assays}

Explant cultures were processed for the assays as previously described $[24,26,28]$. The DNA contents were determined using Hoechst 33258, the proteoglycan contents by binding to the DMMB dye, and those for type-II collagen and type-X collagen by ELISA [24,26,28,47]. Data were normalized to total cellular proteins using a protein assay (Pierce Thermo Scientific, Fisher Scientific, Schwerte, Germany). All measurements were performed with a GENios spectrophotometer/fluorometer (Tecan, Crailsheim, Germany).

\section{Statistical analysis}

Each condition was performed in triplicate in three independent experiments with both types of cultures. Data were obtained by two individuals that were blinded with respect to the treatment groups. Values are expressed as mean \pm standard deviation (SD). The $t$-test and MannWhitney Rank Sum Test were employed where appropriate. $P$ values of less than 0.05 were considered statistically significant.

\section{Results}

rAAV-mediated TGF- $\beta$ overexpression in human normal and $O A$ articular chondrocytes in vitro and in situ

The functionality of the rAAV-hTGF- $\beta$ vector was first tested in human normal and OA primary chondrocyte cultures and articular cartilage explants.

In vitro, significant, sustained (at least 21 days) TGF- $\beta$ expression was noted only in rAAV-hTGF- $\beta$-transduced chondrocytes compared with the control (rAAV-lacZ) condition (normal cells: from $461.2 \pm 7.8$ to $184.2 \pm 3.5$ versus $14.6 \pm 2.1$ to $11.3 \pm 0.9 \mathrm{pg} / \mathrm{ml} / 24 \mathrm{~h}$ between days 5 and 21 ; OA cells: from $552.4 \pm 6.5$ to $219.4 \pm 3.2$ versus $17.5 \pm 3.1$ to $10.6 \pm 0.7 \mathrm{pg} / \mathrm{ml} / 24 \mathrm{~h}$ between days 5 and 21 ; up to 31.6 -fold difference, always $P \leq 0.001$ ), showing durable transduction efficiencies (up to 80\%) (Figure 1A).

Significant, durable (at least 90 days) TGF- $\beta$ expression was also achieved in situ when applying rAAVhTGF- $\beta$ to cartilage explants compared with rAAV-lacZ (normal cartilage: from $724.5 \pm 4.9$ to $304.2 \pm 2.2 \mathrm{ver}$ sus $92.3 \pm 1.1$ to $55.2 \pm 1.9 \mathrm{pg} / \mathrm{ml} / 24 \mathrm{~h}$ between days 21 and 90; OA cartilage: from $987.7 \pm 4.8$ to $324.9 \pm 4.3$ versus $83.4 \pm 2.1$ to $58.1 \pm 3.2 \mathrm{pg} / \mathrm{ml} / 24 \mathrm{~h}$ between days 21 and 90; up to 11.8 -fold difference, always $P \leq$ 0.001 ), with specific immunoreactivity observed both in the superficial and middle zones of the cartilage and showing again durable transduction efficiencies (up to $70 \%$ ) (Figure 1B).
(A)

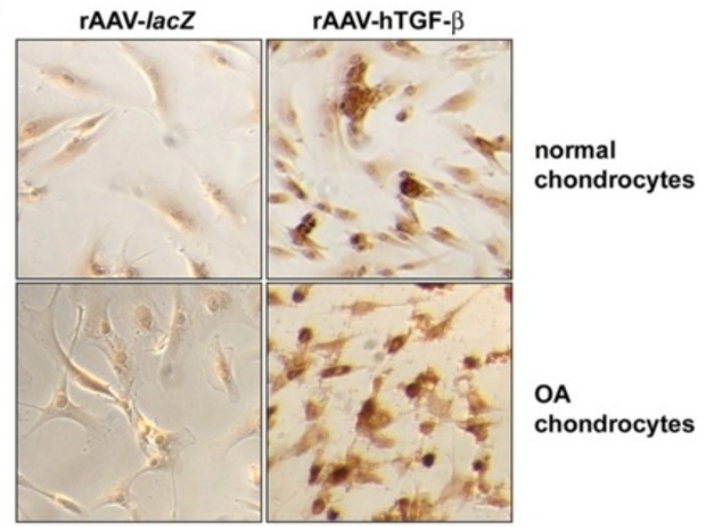

(B)

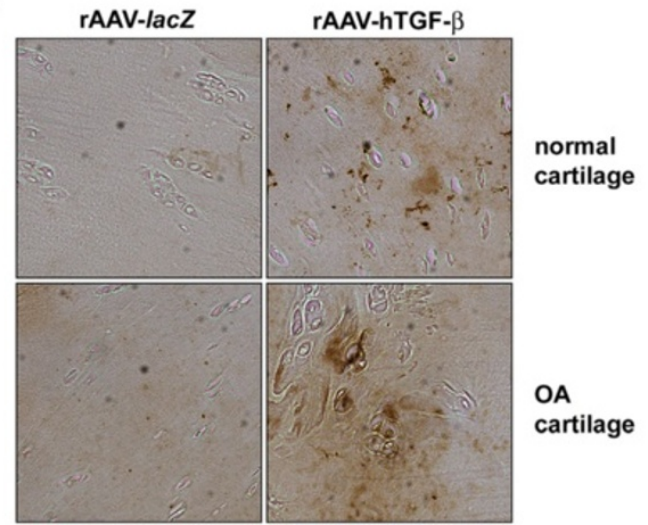

Figure 1 Detection of TGF- $\beta$ expression in rAAV-transduced human normal and $O A$ chondrocytes in vitro and in situ. Cells (A) and explants (B) were transduced by direct administration of the vectors (rAAV-lacZ or rAAV-hTGF- $\beta$ : $40 \mu$ l each vector) and maintained in culture for 21 days in vitro and for 90 days in situ. The samples were then fixed and histologically processed to monitor the expression of TGF- $\beta$ by immunocyto-/-histochemical detection (A: magnification $\times 4$; B: magnification $\times 20$, view of the middle zone).

These results show that the current rAAV TGF- $\beta$ vector is capable of modifying human normal and OA chondrocytes both in vitro and in situ, allowing for significant levels of transgene expression compared with control vector administration over extended periods of time, especially when the cells are embedded in their ECM (at least 90 days in situ).

\section{Effects of rAAV-hTGF- $\beta$ administration upon the cellular} activities of human normal and OA articular chondrocytes in vitro and in situ

We next evaluated the ability of rAAV-mediated TGF- $\beta$ overexpression to stimulate the proliferative and survival activities of chondrocytes in the systems tested above.

In vitro, immunodetection of BrdU incorporation revealed significant and durable (from day 5 to day 21) increases in the levels of cell proliferation with TGF- $\beta$ 
versus lacZ both in normal and OA cells (up to 6.3-fold difference, always $P \leq 0.001$ ) (upper panels of Figures $2 \mathrm{~A}$ and $3 \mathrm{~A}$ ). These results were corroborated by Cell Proliferation ELISA BrdU (0.698 versus 0.605 OD $^{450} \mathrm{~nm}$ in normal cells and 0.680 versus $0.626 \mathrm{OD}^{450} \mathrm{~nm}$ in OA cells; up to 1.2 -fold difference, always $P \leq 0.001$ ) and by analyzing the DNA contents (up to 1.3-fold difference, always $P \leq 0.001$ ) (Figure 3B). Similar results were noted in cartilage explant cultures in situ. Immunodetection

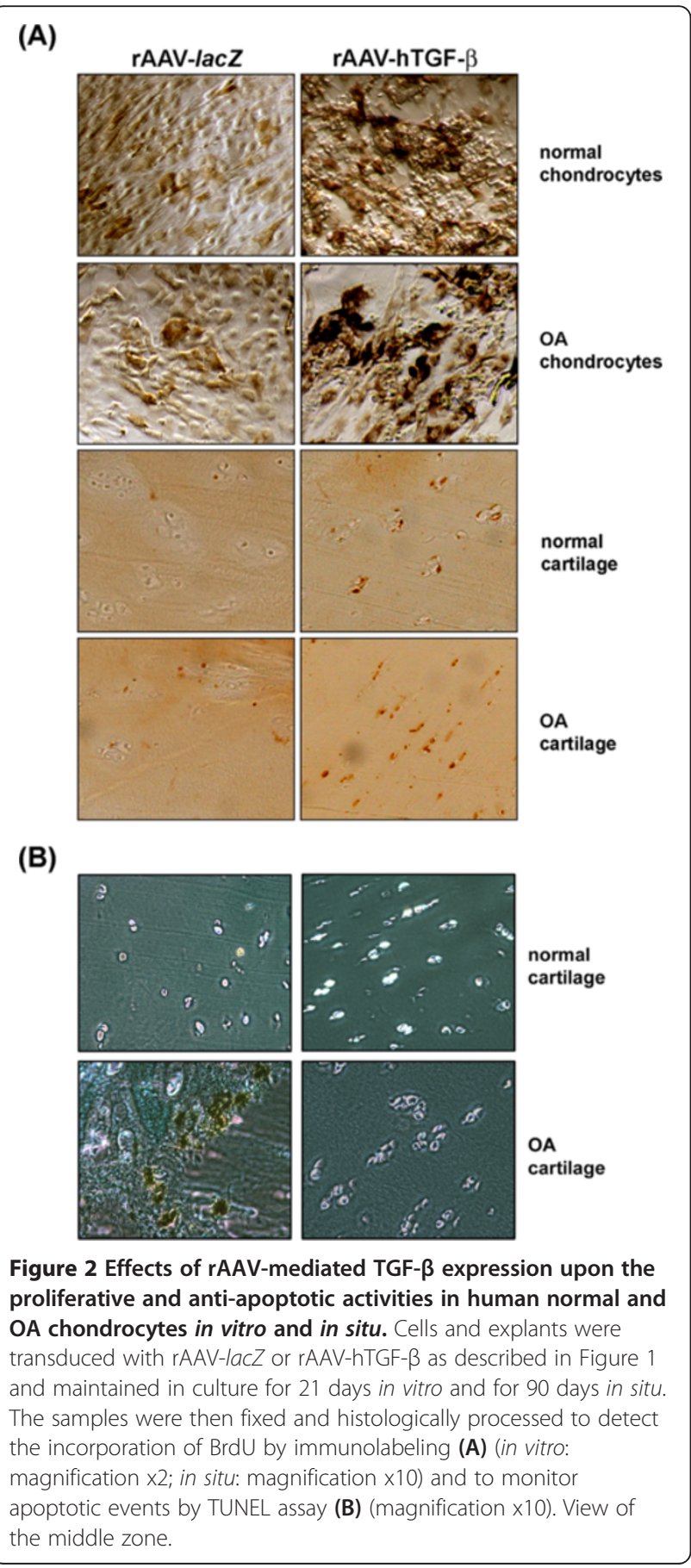

of BrdU incorporation in normal and OA explants demonstrated significant and durable (from day 21 to day 90) increases in the levels of cell proliferation with TGF- $\beta$ versus lac $Z$ (up to 15.8 -fold difference, always $P \leq 0.001$ ) (lower panels of Figures $2 \mathrm{~A}$ and $4 \mathrm{~A}$ ). These findings were substantiated by an analysis of the DNA contents (up to 2.3 -fold difference, always $P \leq 0.001$ ) (Figure 4B) and of the cell densities on histological sections (up to 4.7 -fold difference, always $P \leq 0.001$ ) (Figures $4 \mathrm{C}$ and $5 \mathrm{~A}$ ). Remarkably, these parameters were always higher with TGF- $\beta$ in normal cartilage versus lac $Z$ (always $P \leq 0.001$ ). Of further note, a TUNEL analysis showed that the presence of TGF- $\beta$ significantly and durably (from day 21 to day 90 ) reduced the percentage of apoptotic cells in OA cartilage compared with lacZ (36-fold decrease, $P \leq 0.001$ ), bringing back the levels to those noted in control normal cartilage (almost undetectable levels) (Figures 2B and 4D).

Further biochemical analyses in vitro next revealed significant and durable (from day 5 to day 21) increases in the proteoglycan and type-II collagen contents with TGF- $\beta$ versus lac $Z$ both in normal and OA cells (up to 11.5 -fold difference, always $P \leq 0.001$ ) (Figures $3 \mathrm{C}$ and D) while those for type-X collagen significantly and durably decreased (from day 5 to day 21) with TGF- $\beta$ (up to 1.7-fold difference, $P \leq 0.001$ in OA cells) (Figure 3E). Again, similar results were obtained in cartilage explant cultures in situ. An analysis of the proteoglycan and type-II collagen contents showed significant and durable (from day 21 to day 90) increases with TGF- $\beta$ versus lac $Z$ both in normal and OA cartilage (up to 8.2-fold difference, always $P \leq 0.001$ ) (Figures $4 \mathrm{E}$ and $\mathrm{G}$ ). These findings were substantiated by an analysis of the intensities of safranin $\mathrm{O}$ staining and of type-II collagen immunostaining (up to 17.4-fold difference, always $P \leq 0.001$ ) (Figures 4F,H, 5A, and $B)$. Again, these parameters were always higher with TGF- $\beta$ in normal cartilage versus lac $Z$ (always $P \leq$ 0.001). Also, the contents and immunostaining intensities for type-X collagen significantly and durably (from day 21 to day 90 ) decreased with TGF- $\beta$ (up to 20.5-fold difference, $P \leq 0.001$ in OA cartilage) (Figures 4I, $\mathrm{J}$, and $5 \mathrm{C}$ ).

These findings show that application of rAAV-hTGF$\beta$ is capable of both enhancing the proliferative and anabolic activities of human normal and OA chondrocytes in vitro and in situ while advantageously delaying their terminal differentiation. While the effects of TGF- $\beta$ were in general more robust early on both in vitro and in situ (between 1.1- and 1.7-fold difference), probably due to higher levels of TGF- $\beta$ expression over time (up to 3.04-fold difference), they remained significant $v i s-\grave{a}-v i s$ lac $Z$ at the latest time points evaluated (always $P \leq 0.001$ ). 


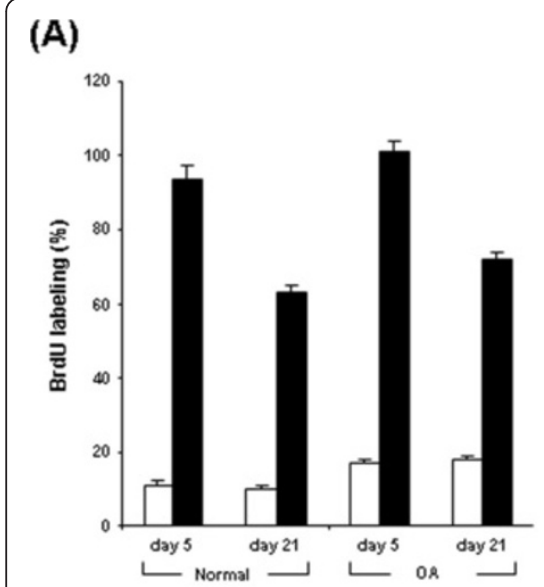

(C)

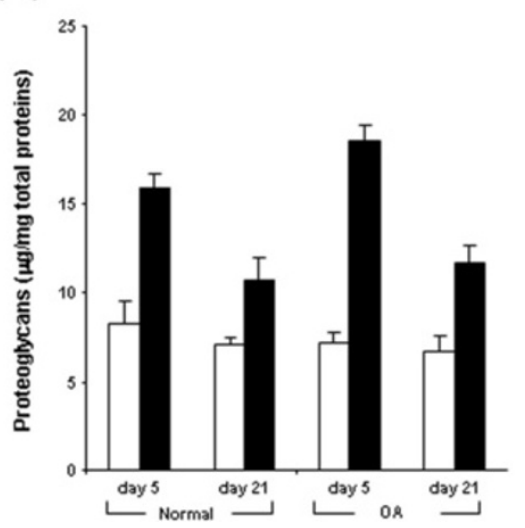

(B)

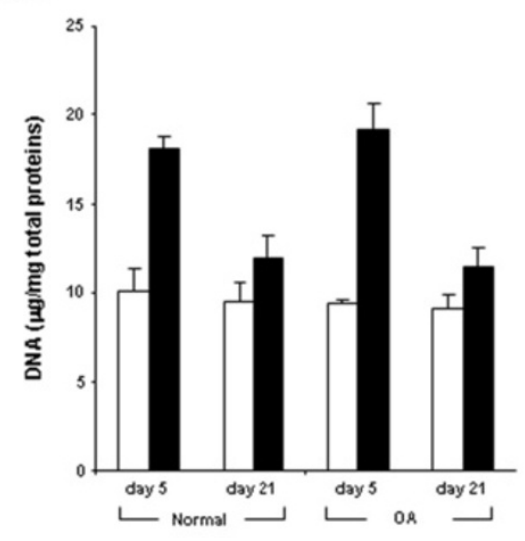

(D)

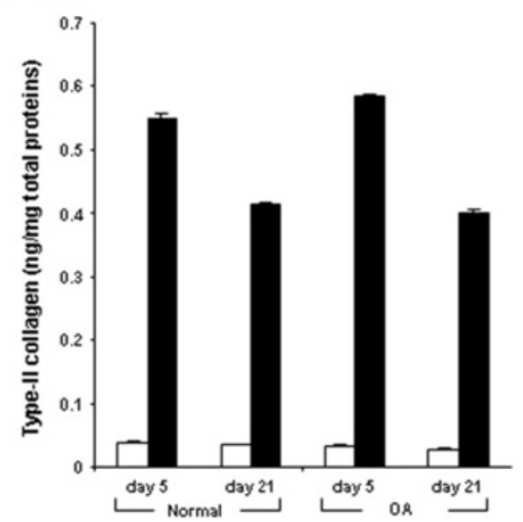

(E)

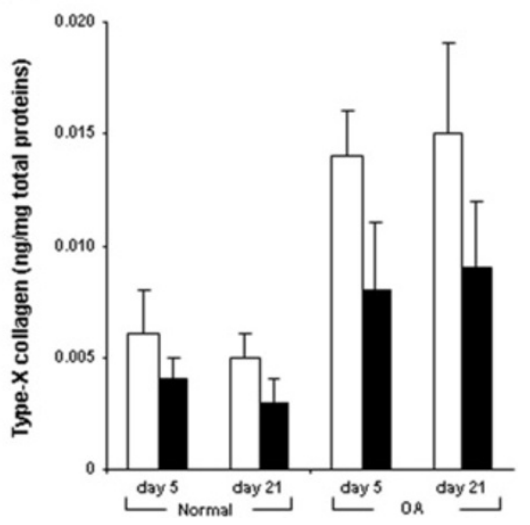

Figure 3 Morphometric and biochemical analyses in rAAV-transduced chondrocytes in vitro. Cells were transduced with rAAV-lacZ or rAAV-hTGF- $\beta$ as described in Figure 1 and maintained in culture for up to 21 days. The samples were then fixed and histologically processed at the denoted time points to monitor the \% of BrdU labeling (A) and the contents of DNA (B), proteoglycans (C), type-II (D) and type-X collagen (E).

Evaluation of the pathways allowing for the long-term protective effects of TGF- $\beta$ via rAAV gene transfer in human normal and OA articular cartilage

To determine the mechanisms possibly involved in the processes of TGF- $\beta$-mediated cartilage remodeling over time via rAAV gene transfer, we investigated the expression of critical chondrocyte differentiation-related and OA-associated factors in the cartilage in situ at the latest time point evaluated in the study (90 days) among which MMP-13 (collagenase-3, a marker of terminal differentiation), the members of the protective TIMP family (TIMP-1 and -3), PTHrP (a hypertrophy-associated agent), $\beta$-catenin (a mediator of the Wnt signaling pathway associated with hypertrophy), and the TGF- $\beta$ receptor I (protective ALK5 signaling pathway versus alternative opposing ALK1 route).

Administration of rAAV-hTGF- $\beta$ to OA cartilage versus rAAV-lacZ promoted a significant decrease in the levels of key components involved in hypertrophic differentiation such as MMP-13 (31-fold, $P \leq 0.001$ ) (Figures 6A and 7A),
PTHrP (22.7-fold, $P \leq 0.001$ ) (Figures 6D and 7D), and $\beta$-catenin (20.7-fold, $P \leq 0.001$ ) (Figures $6 \mathrm{E}$ and $7 \mathrm{E}$ ) while expression of these markers was low in normal cartilage. In contrast, expression of the protective TIMP-1 and TIMP-3 significantly increased following application of TGF- $\beta$ both in normal and OA cartilage (at least 2.3-fold for TIMP-1 and 2.1-fold for TIMP-3, always $P \leq 0.001$ ) (Figures $6 \mathrm{~B}$ and $7 \mathrm{~B}$ and Figures $6 \mathrm{C}$ and $7 \mathrm{C}$, respectively). As a result, the proportion of TIMPs against MMP-13 was significantly higher in TGF- $\beta$ - than in lacZ-treated (control) OA cartilage (39.5 versus 0.5 for TIMP-1/MMP-13, i.e. 79-fold; 41.5 versus 0.6 for TIMP-3/ MMP-13, i.e. 69.2-fold; always $P \leq 0.001$ ) and than in control normal cartilage (22 for TIMP-1/MMP-13, i.e. 1.8-fold; 27 for TIMP-3/MMP-13, i.e. 1.5-fold; always $P \leq 0.001$ ). Transduction with rAAV-hTGF- $\beta$ was also capable of enhancing the expression of the TGF- $\beta$ receptor I in normal and OA cartilage compared with control conditions. Both the levels of ALK1 and ALK5 were significantly up-regulated in response to TGF- $\beta$ 


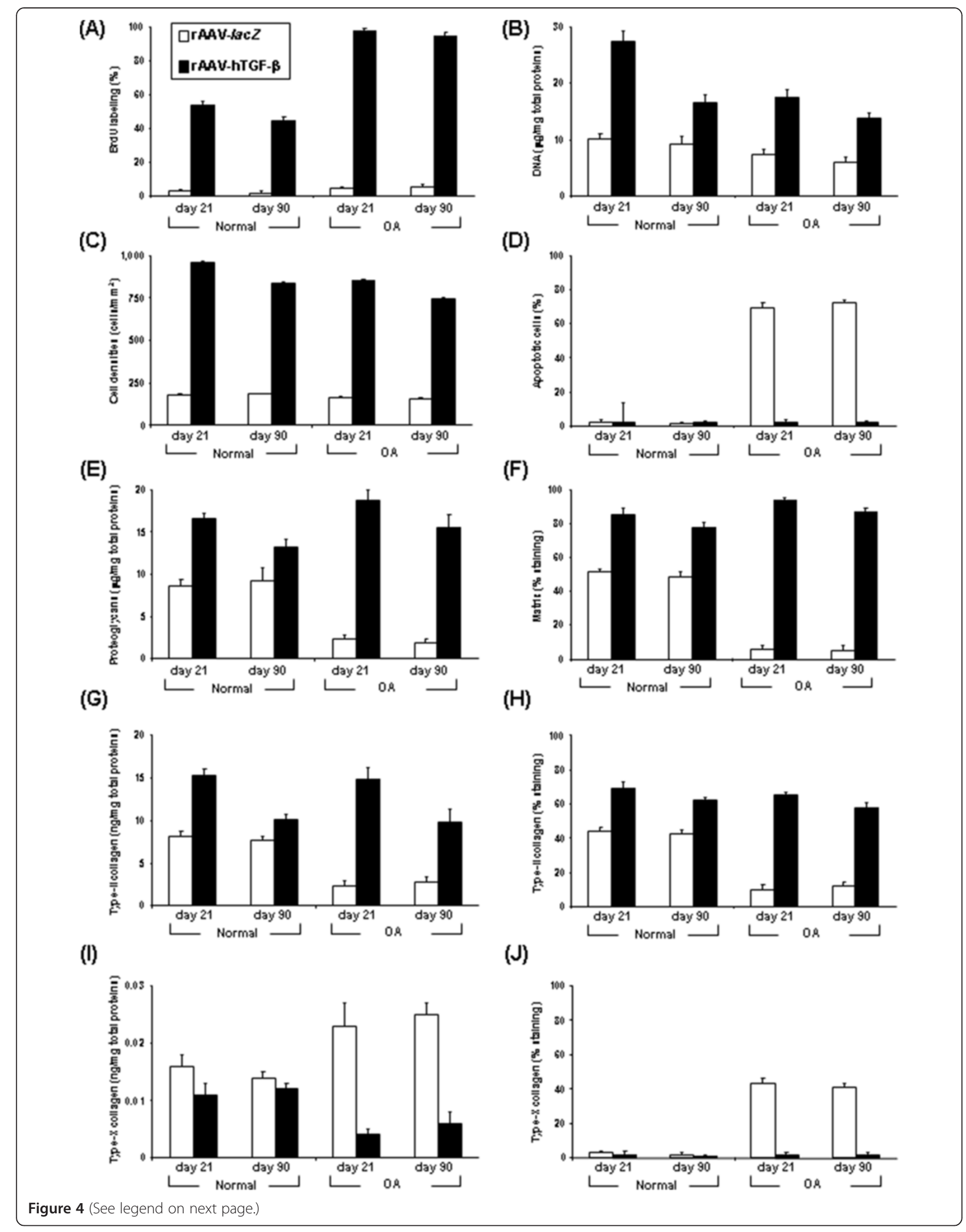


(See figure on previous page.)

Figure 4 Morphometric and biochemical analyses in rAAV-transduced chondrocytes in situ. Explants were transduced with rAAV-lacZ or rAAV-hTGF- $\beta$ as described in Figure 1 and maintained in culture for up to 90 days. The samples were then fixed and histologically processed at the denoted time points to monitor the \% of BrdU labeling (A), the DNA contents (B), cells densities (C), \% of apoptotic cells (D), proteoglycan contents (E), \% of matrix staining (F), type-II collagen contents $(\mathbf{G})$, \% of type-II collagen immunostaining $(\mathbf{H})$, type-X collagen contents (I), and \% of type-X collagen immunostaining $(\mathrm{J})$.

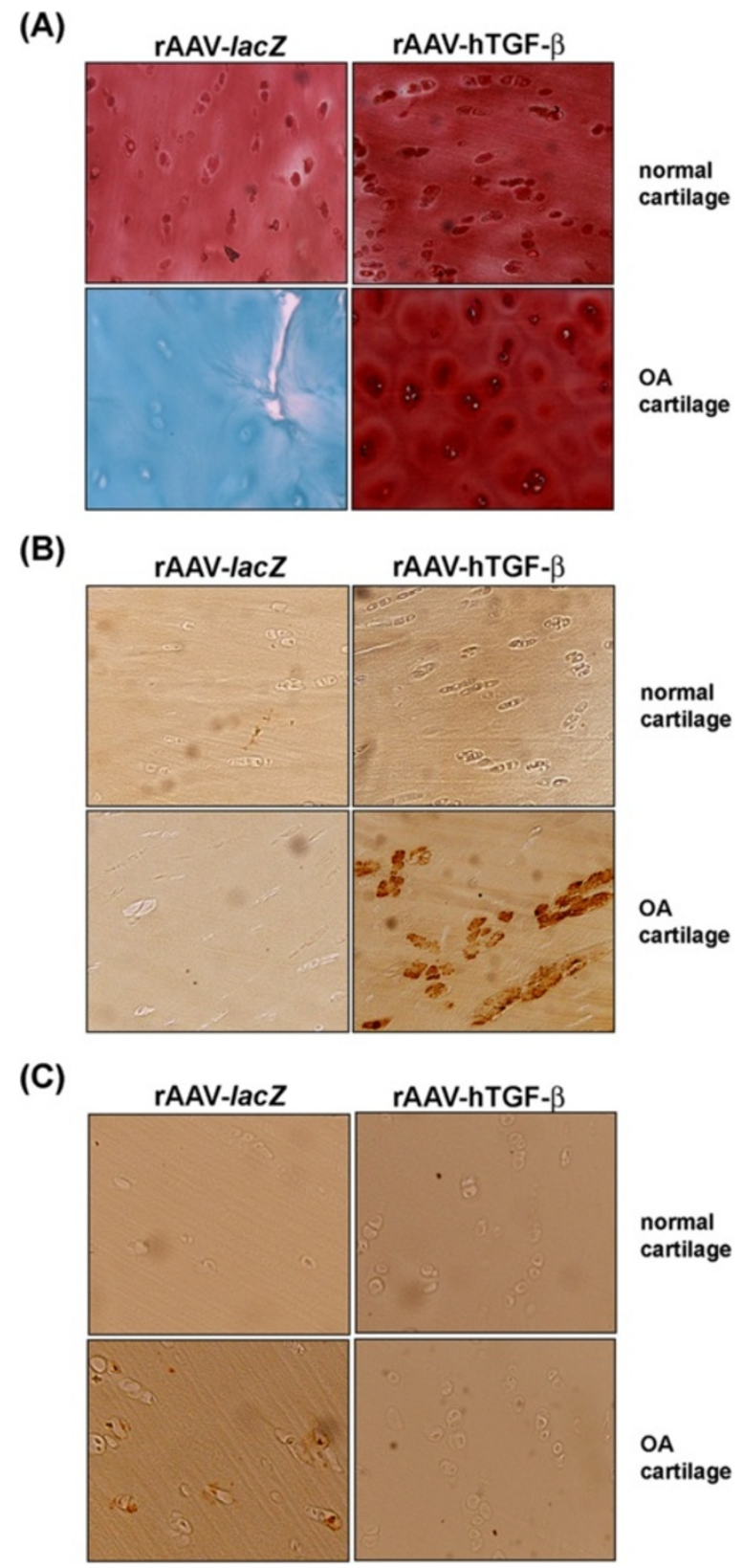

Figure 5 Effects of rAAV-mediated TGF- $\beta$ expression upon the anabolic activities of human normal and $O A$ chondrocytes in situ. Explants were transduced with rAAV-lacZ or rAAV-hTGF- $\beta$ as described in Figure 1 and maintained in culture for 90 days. The samples were then fixed and histologically processed for safranin $O$ staining (A) and immunohistochemical detection of type-II (B) and type-X collagen (C) (all at magnification $\times 10$; view of the middle zone).
(ALK1: 1.6-fold in normal and 5.1-fold in OA cartilage; always $P \leq 0.001$; ALK5: 1.6 -fold in normal and 23.3fold in OA cartilage; always $P \leq 0.001$ ) (Figures $6 \mathrm{~F}$ and $7 \mathrm{~F}$ and Figures $6 \mathrm{G}$ and $7 \mathrm{G}$, respectively). Strikingly, while similar increases were noted for ALK1 and ALK5 in normal cartilage with TGF- $\beta$ allowing to maintain the ALK1/ALK5 ratio to $~ 1.1$ like in the corresponding controls (Figure $7 \mathrm{H}$ ), application of the therapeutic vector to OA cartilage enhanced the ALK5 levels to those noted for ALK1 thus re-establishing a standard ALK1/ ALK5 balance in OA $(\sim 1.0)$ versus a shift towards increased, unfavorable ALK1 noted in damaged, control cartilage $(\sim 4.7)$ (Figure $7 \mathrm{H})$.

These findings indicate that treatment of human OA cartilage with the candidate rAAV TGF- $\beta$ vector beneficially impacts the processes of chondrocyte hypertrophy and terminal differentiation in human OA chondrocytes in situ via the TGF- $\beta$ signaling pathway.

\section{Discussion}

\section{Study goals}

Direct therapeutic gene transfer based on the use of the efficient and stable rAAV vectors is a promising tool to manage the irreversible progression of OA. In this regard, TGF- $\beta$ might be a good candidate to achieve this goal due to its protective and reparative effects in the articular cartilage [32,33]. Notably, Ulrich-Vinther et al. [34] reported that gene transfer of TGF- $\beta$ via rAAV was capable of increasing the levels of key ECM components while decreasing those of MMP-3 over a one-week period of time in human OA chondrocytes in vitro, yet the benefits of such an approach upon the long-term remodeling of human OA cartilage especially in situ remain to be elucidated. In the present study, we therefore examined whether an rAAV-hTGF- $\beta$ vector can effectively and durably modify primary human normal and OA articular chondrocytes in vitro and most importantly in cartilage explant cultures in situ, leading to a prolonged activation of remodeling activities compared with control treatment.

rAAV mediates successful overexpression TGF- $\beta$ in human normal and $O A$ articular chondrocytes in vitro and in situ For the first time to our best knowledge, we show that efficient, sustained TGF- $\beta$ expression can be promoted by rAAV gene transfer both in human normal and OA 


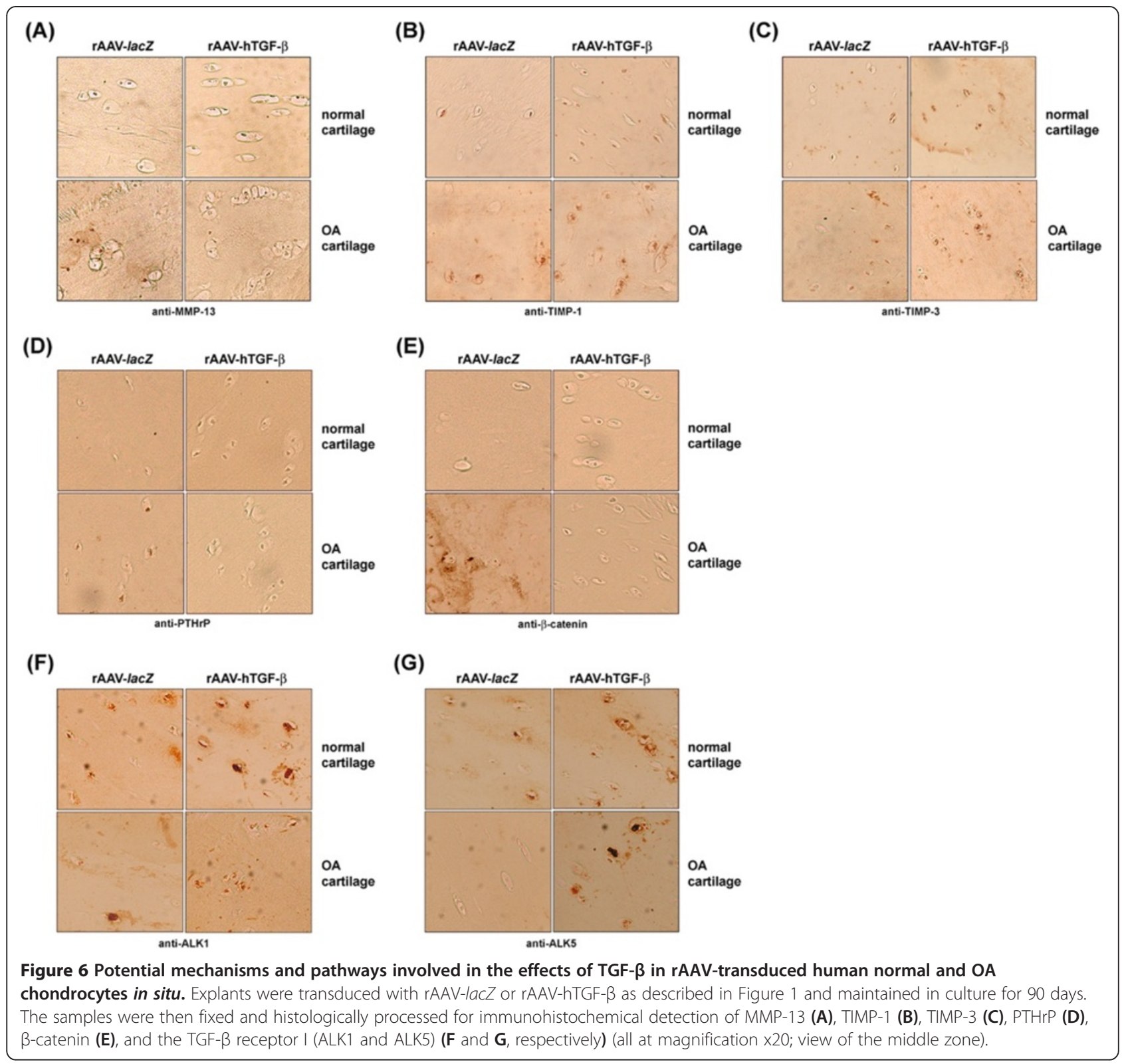

chondrocytes in vitro for at least 21 days and in human normal and OA cartilage explants in situ for at least 90 days, probably resulting from the persistence of rAAV in the targets [24], and with transduction efficiencies reaching $70-80 \%$ in these systems, in good agreement with previous findings using this class of vector $[24,26,28,34,37,38]$. The levels of production achieved here early on in vitro with rAAV (up to $552.4 \mathrm{pg} \mathrm{TGF}-\beta / \mathrm{ml} / 24 \mathrm{~h}$ on day 5 at an MOI $=40$ ) were in the range of those reported by Ulrich-Vinther et al. at a similar time point $(5 \mathrm{ng} / \mathrm{ml} / 24 \mathrm{~h}$ on day 8 at an $\mathrm{MOI}=250$ ) [34]. For comparison, the levels of expression reached $60 \mathrm{ng} / \mathrm{ml} / 24 \mathrm{~h}$ with a nonviral vector but in bovine chondrocytes and using a very high amount of plasmid $(2 \mu \mathrm{g})$ [48], $2.5 \mathrm{ng} / \mathrm{ml} / 24 \mathrm{~h}$ with an adenoviral vector at an MOI of 50 but in a human chondrocyte-like cell line [35], and $20-33 \mathrm{ng} / 10^{5}$ cells $/ 24$ h (i.e. $4-7 \mathrm{ng} /$ $2 \times 10^{4}$ cells $/ 24 \mathrm{~h}$ ) in human chondrocytes with retroviral vectors but tested upon selection of transduced cells $[40,41]$. However, only very short-term expression was noted with these classes of vectors (never beyond 4 days) while we describe an ongoing, significant synthesis until day 21 (up to $219.4 \mathrm{pg} / \mathrm{ml} / 24 \mathrm{~h}$ ). Most remarkably, and for the first time, we further evidenced a sustained production of TGF- $\beta$ in situ via rAAV (up to 90 days), reaching levels of up to $987.7 \mathrm{pg} / \mathrm{ml} / 24 \mathrm{~h}$ and 


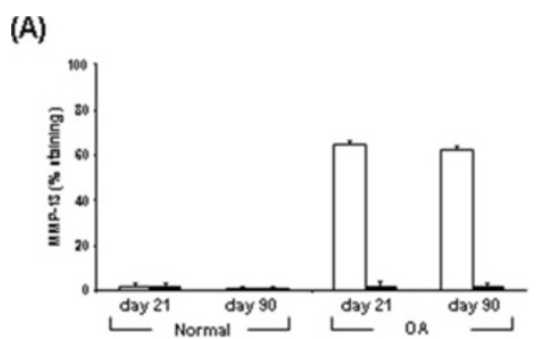

(D)

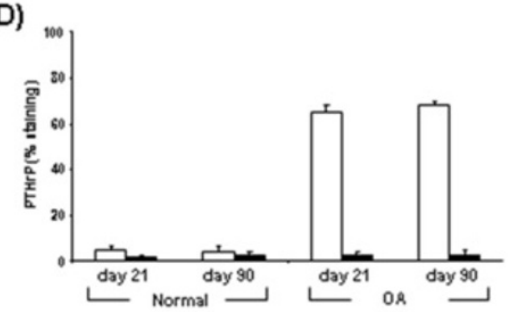

(F)

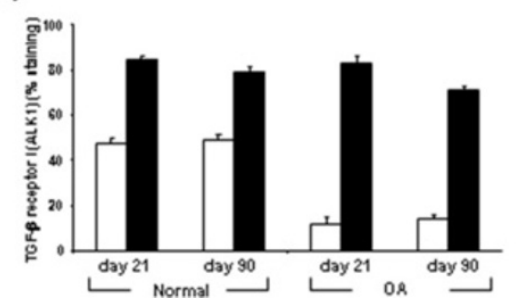

(B)

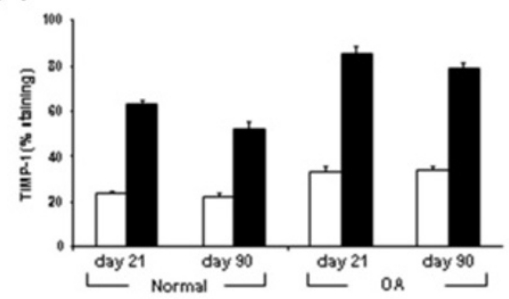

(E)

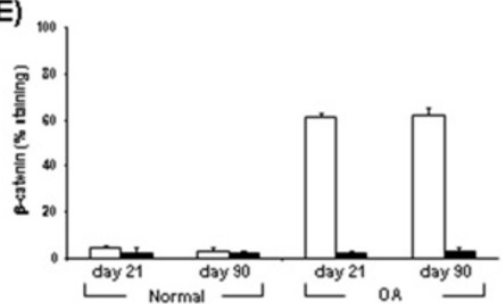

(G)

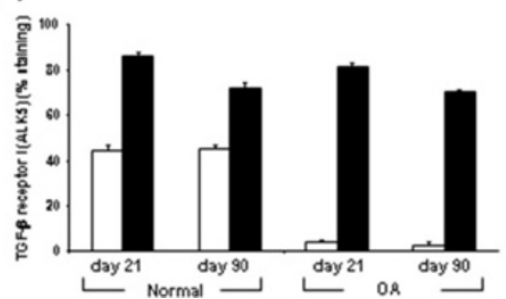

(C)

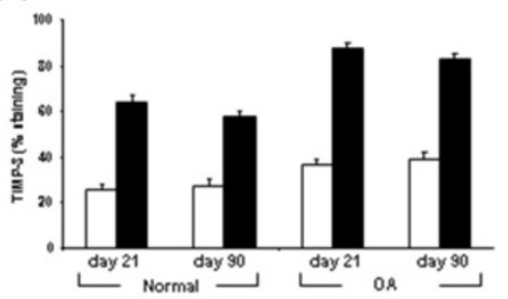

DrAAV-SacZ

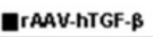

(H)

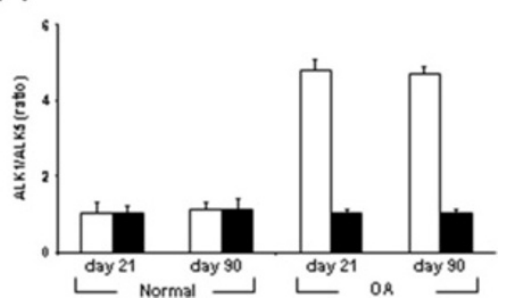

Figure 7 Morphometric analyses of mechanisms and pathways in rAAV-transduced chondrocytes in situ. Explants were transduced with rAAV-lacZ or rAAV-hTGF- $\beta$ as described in Figure 1 and maintained in culture for up to 90 days. The samples were then fixed and histologically processed at the denoted time points to monitor the \% of cells immunostained for MMP-13 (A), TIMP-1 (B), TIMP-3 (C), PTHrP (D), $\beta$-catenin (E), and the TGF- $\beta$ receptor I (ALK1 and ALK5) (F and G, respectively). Data on the ALK1/ALK5 ratio are presented in $(\mathbf{H})$.

occurring through the whole thickness of the cartilage, probably due to the ability of the small rAAV particles to penetrate the dense matrix $[24,26,28,38]$.

\section{rAAV-mediated TGF- $\beta$ overexpression activates the} proliferative and anabolic activities of human normal and OA articular chondrocytes in vitro and in situ

The data further indicate that such high, maintained levels of rAAV-delivered TGF- $\beta$ stimulated both the proliferative, survival, and biosynthetic activities of human normal and OA chondrocytes in vitro and in situ over time compared with control treatments, consistent with the properties of the growth factor [23,34-36,39-41]. A rigorous comparison of the effects of TGF- $\beta$ resulting from rAAV gene transfer compared with other vector classes is difficult to establish as divergent assessment methods have been used in these earlier studies [23,34-36,39-41]. Nevertheless, it is noteworthy that only short-term effects of the growth factor have been demonstrated there (only some few days) or following cell selection, and mostly in in vitro settings, whereas we report prolonged effects both in vitro and most significantly in situ.
rAAV-mediated TGF- $\beta$ overexpression delays chondrocyte hypertrophy and terminal differentiation in situ via the TGF- $\beta$ signaling pathway

Furthermore, application of the current TGF- $\beta$ construct led to advantageous decreases in the expression of key OA-associated markers of chondrocyte hypertrophic and terminal differentiation like type-X collagen, MMP-13, PTHrP, and $\beta$-catenin, again in agreement with the effects of this growth factor $[49,50]$. In contrast, TGF- $\beta$ overexpression increased (although to a lesser extent) the levels of protective TIMPs as previously described [51,52], allowing nevertheless to beneficially influence the balance between TIMPs and MMP-13 and suggesting that other pathways might be implicated. Most strikingly, we show that efficient, sustained production of TGF- $\beta$ via rAAV significantly enhanced the levels of the critical TGF- $\beta$ receptor I as previously reported [53], both for the ALK1 and ALK5 signaling pathways but in a fashion that restored a favorable, original ALK1/ALK5 balance in OA cartilage like in control normal cartilage [54,55], allowing to overcome the age- and OA-associated changes in TGF- $\beta$ signaling [56] and probably resulting in the modulation of hypertrophic and terminal differentiation processes [54]. 


\section{Perspectives}

Interestingly, overexpression of TGF- $\beta$ in the conditions applied here led to enhanced biological activities in human OA cells and cartilage compared with control normal cells and cartilage. It remains to be seen whether such prominent activities will not alter the cell activities and cartilage and joint integrity over time especially in vivo, in light of reports showing adverse effects of TGF- $\beta$ delivery in experimental animal models (synovial inflammation and fibrosis, osteophyte formation) [57-62]. Still, in these studies, detrimental effects were evidenced when very high amounts of recombinant factor were applied (100-200 ng while we report up to $987.7 \mathrm{pg}$ biologically active TGF- $\beta / \mathrm{ml} / 24 \mathrm{~h}$ with $\mathrm{rAAV}$ in situ), in a dose-dependent and recurrent manner [62], or following adenoviral-mediated gene transfer at much higher doses than those used here $\left(10^{7}-10^{9}\right.$ versus $8 \times 10^{5}$ viral particles) [57-61]. It is also important to note that in all these studies, administration of the treatments was performed by intra-articular injection, a setting where the gene vector and recombinant factor can target all the tissues of the joint, allowing TGF- $\beta$ to possibly exert chemoattractant, inflammatory, and chondrogenic effects especially upon the periosteum, subchondral bone, and synovium [63-65] that is highly permissive to gene transfer [66].

In any case, careful optimization of rAAV TGF- $\beta$ delivery and expression in vivo (dose, duration, localization) will be necessary to establish an effective and appropriate treatment for human OA that takes advantage of the favorable actions of the growth factor over its potentially deleterious effects. Beside injecting low vector doses as performed here, the use of regulatable (tetracyclinesensitive), disease-inducible (NF- $\mathrm{B}, \mathrm{COX}-2$, proinflammatory cytokines), or tissue-specific control elements (SOX9, type-II collagen, cartilage oligomeric matrix protein) may permit to modulate transgene expression compared with the strong CMV-IE promoter. Another important consideration will be to carefully decide on the route of administration. Instead of a conventional approach by intra-articular injection, direct local application of the vector preparation to the sites of cartilage injury might be more favorable to prevent dilution of the treatment in the joint space leading to undesirable dissemination and uptake by surrounding tissues. This will be practicable only when some cartilage surface is remaining like in early stages of $\mathrm{OA}$ and transplantation of TGF- $\beta$-modified cells might be needed for more advanced cases of the disease, having the further advantages of containing the TGF- $\beta$ transgene [67] and avoiding transduction of other joint tissues. In this regard, it is interesting to note that Ha et al. [68] reported the feasibility of delivering retrovirally TGF- $\beta$-modified chondrocytes in patients with severe OA (TissueGene-C dose-escalating phase I clinical trial) with a trend toward efficacy and without serious adverse effects, in marked contrast with findings in experimental systems showing deleterious effects of TGF- $\beta$ (inflammation, fibrosis, osteophyte formation) when provided at very high and repeated doses [57-62]. Again, rAAV might be best suited to develop such indirect, ex vivo trials as their high transduction efficiencies allow to use them without having to preselect the transduced cells compared with retroviral vectors [40,41,67].

Finally, administration of other candidates in conjunction with TGF- $\beta$ (concomittently or sequentially) might be necessary, especially those that can specifically counteract the side effects of the growth factor or of its putative secondary mediators (fibrotic CTGF, BMP-2 in the case of osteophyte formation) like the inhibitory Smad6 and Smad7 and antagonist gremlin [58,59,69]. Alternatively, agents like IL-1Ra or IL-1 siRNA, sTNFR, NF-kB inhibitors, KBP, TSP-1, DKK-1, POMC, sFlt-1 (a VEGF antagonist) $[11,13-21,27]$ might provide other good options to achieve this goal. Again rAAV might be a powerful tool to achieve these goals as combined gene transfer with this class of vector has been demonstrated in the current systems evaluated [26].

\section{Final remarks}

In summary, the results of the present study indicate that for the first time and in marked contrast with other classes of vectors, the direct, prolonged overexpression of TGF- $\beta$ via rAAV vectors can efficiently stimulate the reparative activities of human normal and OA chondrocytes over time in vitro and most importantly in situ, contributing to the significant, proper remodeling of human OA cartilage. Future studies will allow to determine the benefits of applying the rAAV-hTGF- $\beta$ construct in an appropriate, clinically relevant experimental OA model in vivo, requiring to translate first the current findings in the corresponding animal cells. The present findings validate the concept of using rAAV as an effective treatment for human OA.

\section{Conclusion}

$\mathrm{OA}$ is an incurable joint disease that disables millions of people worldwide, remaining very difficult to manage. Gene-based approaches may provide long-term treatments to restore an original structure and integrity in OA cartilage by rejuvenating resident (or transplanted) cells. The safe and highly efficient rAAV vectors are particularly well suited to treat OA that is not a lifethreatening disease. Here, we showed the potency of an rAAV TGF- $\beta$ vector to remodel human OA cartilage over extended, clinically relevant periods of time. The effects of this therapeutic vector in vivo and upon other affected tissues in the OA joint remain now to be investigated. 


\section{Competing interests}

The authors declare that they have no competing interests.

\section{Authors' contributions}

JKV prepared the vectors and carried out the experiments on gene transfer, cell proliferation and apoptosis, morphometric analyses, and biochemical assays. ARR titrated the vectors and carried out the experiments on transgene expression, histological/immunohistochemical/morphometric analyses, and biochemical assays. GS prepared the cartilage and cell samples for culture and processing and participated in the experiments on morphometric analyses and biochemical assays. AW participated in the experiments on transgene expression, biochemical assays, and statistical analyses. HM participated in the design of the study and helped to draft the manuscript. MC conceived, designed, and coordinated the study, performed the statistical analyses, and wrote the manuscript. All authors read and approved the final manuscript. No writing assistance was used in the production of the manuscript.

\section{Acknowledgements}

This work was supported by the German Research Society (Deutsche Forschungsgemeinschaft) (grants DFG CU 55/1-1,/1-2, and/1-3 to MC and HM) and the German Osteoarthritis Foundation (Deutsche Arthrose-Hilfe) (grants to MC and HM). The authors thank RJ Samulski (The Gene Therapy Center, University of North Carolina, Chapel Hill, NC, USA) and X Xiao (The Gene Therapy Center, University of Pittsburgh, Pittsburgh, PA, USA) for providing the genomic AAV-2 plasmid clones, the pXX2 and pXX6 plasmids, and the 293 cell line.

\section{Author details}

${ }^{1}$ Center of Experimental Orthopaedics, Saarland University Medical Center, Kirrbergerstr. Bldg 37, Homburg/Saar 66421, Germany. ²Department of Orthopaedic Surgery, Saarland University Medical Center, Homburg/Saar, Germany.

Received: 4 July 2013 Accepted: 11 September 2013

Published: 13 September 2013

\section{References}

1. Loeser RF, Goldring SR, Scanzello CR, Goldring MB: Osteoarthritis: a disease of the joint as an organ. Arthritis Rheum 2012, 64:1697-1707.

2. Lories RJ, Luyten FP: The bone-cartilage unit in osteoarthritis. Nat Rev Rheumatol 2011, 7:43-49.

3. Lotz M: Osteoarthritis year 2011 in review: biology. Osteoarthritis Cartilage 2012, 20:192-196.

4. Poole AR: Osteoarthritis as a whole joint disease. HSS J 2012, 8:4-6.

5. van den Berg WB: Osteoarthritis year 2010 in review: pathomechanisms. Osteoarthritis Cartilage 2006, 19:338-341.

6. Guilak F: Biomechanical factors in osteoarthritis. Best Pract Res Clin Rheumatol 2011, 25:815-823.

7. Kraus VB, Burnett B, Coindreau J, Cottrell S, Eyre D, Gendreau M, Gardiner J, Garnero P, Hardin J, Henrotin Y, Heinegard D, Ko A, Lohmander LS, Matthews G, Menetski J, Moskowitz R, Persiani S, Poole AR, Rousseau JC, Todman M, OARSI FDA Osteooarthritis Biomarkers Working Group: Application of biomarkers in the development of drugs intended for the treatment of osteoarthritis. Osteoarthritis Cartilage 2011, 19:515-542.

8. Sandell LJ: Etiology of osteoarthritis: genetics and synovial joint development. Nat Rev Rheumatol 2012, 8:77-89.

9. Goldring MB, Otero M: Inflammation in osteoarthritis. Curr Opin Rheumatol 2011, 23:471-478

10. Kapoor M, Martel-Pelletier J, Lajeunesse D, Pelletier JP, Fahmi H: Role of proinflammatory cytokines in the pathophysiology of osteoarthritis. Nat Rev Rheumatol 2011, 7:33-42.

11. Chen LX, Lin L, Wang HJ, Wei XL, Fu X, Zhang JY, Yu CL: Suppression of early experimental osteoarthritis by in vivo delivery of the adenoviral vector-mediated NF-kappaBp65-specific siRNA. Osteoarthritis Cartilage 2008, 16:174-184.

12. Chu X, You H, Yuan X, Zhao W, Li W, Guo X: Protective effect of lentivirusmediated siRNA targeting ADAMTS- 5 on cartilage degradation in a rat model of osteoarthritis. Int J Mol Med 2013, 31:1222-1228.

13. Fernandes J, Tardif G, Martel-Pelletier J, Lascau-Coman V, Dupuis M, Moldovan F, Sheppard M, Krishnan BR, Pelletier JP: In vivo transfer of interleukin-1 receptor antagonist gene in osteoarthritic rabbit knee joints: prevention of osteoarthritis progression. Am J Pathol 1999, 154:1159-1169.

14. Frisbie DD, Ghivizzani SC, Robbins PD, Evans CH, Mcllwraith CW: Treatment of experimental equine osteoarthritis by in vivo delivery of the equine interleukin-1 receptor antagonist gene. Gene Ther 2002, 9:12-20.

15. Ghivizzani SC, Lechman ER, Kang R, Tio C, Kolls J, Evans CH, Robbins PD: Direct adenovirus-mediated gene transfer of interleukin 1 and tumor necrosis factor alpha soluble receptors to rabbit knees with experimental arthritis has local and distal anti-arthritic effects. Proc Natl Acad Sci U S A 1998, 95:4613-4618.

16. Hsieh JL, Shen PC, Shiau AL, Jou IM, Lee CH, Teo ML, Wang CR, Chao J, Chao L, Wu CL: Adenovirus-mediated kallistatin gene transfer ameliorates disease progression in a rat model of osteoarthritis induced by anterior cruciate ligament transection. Hum Gene Ther 2009, 20:147-158.

17. Hsieh JL, Shen PC, Shiau AL, Jou IM, Lee CH, Wang CR, Teo ML, Wu CL: Intraarticular gene transfer of thrombospondin-1 suppresses the disease progression of experimental osteoarthritis. J Orthop Res 2010, 28:1300-1306.

18. Nixon AJ, Goodrich LR, Scimeca MS, Witte TH, Schnabel LV, Watts AE, Robbins PD: Gene therapy in musculoskeletal repair. Ann N Y Acad Sci 2007, 1117:310-327.

19. Oh H, Chun $\mathrm{CH}$, Chun JS: Dkk-1 expression in chondrocytes inhibits experimental osteoarthritic cartilage destruction in mice. Arthritis Rheum 2012, 64:2568-2578.

20. Santangelo KS, Nuovo GJ, Bertone AL: In vivo reduction or blockade of interleukin-1 beta in primary osteoarthritis influences expression of mediators implicated in pathogenesis. Osteoarthritis Cartilage 2012, 20:1610-1618

21. Shen PC, Shiau AL, Jou IM, Lee CH, Tai MH, Juan HY, Lin PR, Liu GS, Wu CL, Hsieh HL: Inhibition of cartilage damage by pro-opiomelanocortin prohormone overexpression in a rat model of osteoarthritis. Exp Biol Med 2011, 236:334-340.

22. Ruan MZ, Erez A, Guse K, Dawson B, Bertin T, Chen Y, Jiang MM, Yustein J, Gannon F, Lee BH: Proteoglycan 4 expression protects against the development of osteoarthritis. Sci Transl Med 2013, 5:176ra134.

23. Smith P, Shuler FD, Georgescu HI, Ghivizzani SC, Johnstone B, Niyibizi C, Robbins PD, Evans CH: Genetic enhancement of matrix synthesis by articular chondrocytes: comparison of different growth factor genes in the presence and absence of interleukin-1. Arthritis Rheum 2000, 43:1156-1164.

24. Weimer A, Madry H, Venkatesan JK, Schmitt G, Frisch J, Wezel A, Jung J, Kohn D, Terwilliger EF, Trippel SB, Cucchiarini M: Benefits of recombinant adeno-associated virus (rAAV)-mediated insulin-like growth factor I (IGF-I) overexpression for the long-term reconstruction of human osteoarthritic cartilage by modulation of the IGF-I axis. Mol Med 2012, 18:346-358.

25. Chen B, Qin J, Wang H, Magdalou J, Chen L: Effects of adenovirusmediated bFGF, IL-1Ra and IGF-1 gene transfer on human osteoarthritic chondrocytes and osteoarthritis in rabbits. Exp Mol Med 2010, 42:684-695.

26. Cucchiarini M, Terwilliger EF, Kohn D, Madry H: Remodelling of human osteoarthritic cartilage by FGF-2, alone or combined with Sox9 via rAAV gene transfer. J Cell Mol Med 2009, 13:2476-2488.

27. Matsumoto T, Cooper GM, Gharaibeh B, Meszaros LB, Li G, Usas A, Fu FH, Huard J: Cartilage repair in a rat model of osteoarthritis through intraarticular transplantation of muscle-derived stem cells expressing bone morphogenetic protein 4 and soluble Flt-1. Arthritis Rheum 2009, 60:1390-1405.

28. Cucchiarini M, Thurn T, Weimer A, Kohn D, Terwilliger EF, Madry H: Restoration of the extracellular matrix in human osteoarthritic articular cartilage by overexpression of the transcription factor SOX9. Arthritis Rheum 2007, 56:158-167.

29. Li Y, Tew SR, Russell AM, Gonzalez KR, Hardingham TE, Hawkins RE: Transduction of passaged human articular chondrocytes with adenoviral, retroviral, and lentiviral vectors and the effects of enhanced expression of SOX9. Tissue Eng 2004, 10:575-584.

30. O'Keefe RJ, Puzas JE, Brand JS, Rosier RN: Effect of transforming growth factor-beta on DNA synthesis by growth plate chondrocytes: modulation by factors present in serum. Calcif Tissue Int 1988, 43:352-358.

31. Redini F, Galera P, Mauviel A, Loyau G, Pujol JP: Transforming growth factor beta stimulates collagen and glycosaminoglycan biosynthesis in cultured rabbit articular chondrocytes. FEBS Lett 1988, 234:172-176. 
32. Malemud CJ: The role of growth factors in cartilage metabolism. Rheum Dis Clin North Am 1993, 19:569-580.

33. Van Beuningen HM, van der Kraan PM, Arntz OJ, van den Berg WB: Protection from interleukin 1 induced destruction of articular cartilage by transforming growth factor beta: studies in anatomically intact cartilage in vitro and in vivo. Ann Rheum Dis 1993, 52:185-191.

34. Ulrich-Vinther M, Stengaard C, Schwarz EM, Goldring MB, Soballe K: Adeno-associated vector mediated gene transfer of transforming growth factor-beta1 to normal and osteoarthritic human chondrocytes stimulates cartilage anabolism. Eur Cell Mater 2005, 10:40-50.

35. Arai Y, Kubo T, Kobayashi K, Takeshita K, Takahashi K, Ikeda T, Imanishi J, Takigawa M, Hirasawa Y: Adenovirus vector-mediated gene transduction to chondrocytes: in vitro evaluation of therapeutic efficacy of transforming growth factor-beta 1 and heat shock protein 70 gene transduction. J Rheumatol 1997, 24:1787-1795.

36. Shuler FD, Georgescu HI, Niyibizi C, Studer RK, Mi Z, Johnstone B, Robbins $P D$, Evans $C H$ : Increased matrix synthesis following adenoviral transfer of a transforming growth factor beta1 gene into articular chondrocytes. J Orthop Res 2000, 18:585-592.

37. Arai Y, Kubo T, Fushiki S, Mazda O, Nakai H, Iwaki Y, Imanishi J, Hirasawa Y: Gene delivery to human chondrocytes by an adeno-associated virus vector. J Rheumatol 2000, 27:979-982

38. Madry H, Cucchiarini M, Terwilliger EF, Trippel SB: Recombinant adeno-associated virus vectors efficiently and persistently transduce chondrocytes in normal and osteoarthritic human articular cartilage. Hum Gene Ther 2003, 14:393-402.

39. Shi S, Mercer S, Eckert GJ, Trippel SB: Regulation of articular chondrocyte aggrecan and collagen gene expression by multiple growth factor gene transfer. J Orthop Res 2012, 30:1026-1031.

40. Lee DK, Choi KB, Oh IS, Song SU, Hwang S, Lim CL, Hyun JP, Lee HY, Chi GF, Yi Y, Yip V, Kim J, Lee EB, Noh MJ, Lee KH: Continuous transforming growth factor beta1 secretion by cell-mediated gene therapy maintains chondrocyte redifferentiation. Tissue Eng 2005, 11:310-318.

41. Song SU, Cha YD, Han JU, Oh IS, Choi KB, Yi Y, Hyun JP, Lee HY, Chi GF, Lim CL, Ganjei JK, Noh MJ, Kim SJ, Lee DK, Lee KH: Hyaline cartilage regeneration using mixed human chondrocytes and transforming growth factor-beta1-producing chondrocytes. Tissue Eng 2005 11:1516-1526.

42. Mankin HJ, Dorfman H, Lippiello L, Zarins A: Biochemical and metabolic abnormalities in articular cartilage from osteo-arthritic human hips. II. Correlation of morphology with biochemical and metabolic data. J Bone Joint Surg Am 1971, 53:523-537.

43. Samulski RJ, Chang LS, Shenk T: A recombinant plasmid from which an infectious adeno-associated virus genome can be excised in vitro and its use to study viral replication. J Virol 1987, 61:3096-3101.

44. Samulski RJ, Chang LS, Shenk T: Helper-free stocks of recombinant adeno-associated viruses: normal integration does not require viral gene expression. J Virol 1989, 63:3822-3828.

45. Xiao X, Li J, Samulski RJ: Production of high-titer recombinant adeno-associated virus vectors in the absence of helper adenovirus. J Virol 1998, 72:2224-2232.

46. Cucchiarini M, Ekici M, Schetting S, Kohn D, Madry H: Metabolic activities and chondrogenic differentiation of human mesenchymal stem cells following recombinant adeno-associated virus-mediated gene transfer and overexpression of fibroblast growth factor 2. Tissue Eng Part A 2011, 17:1921-1933

47. Venkatesan JK, Ekici M, Madry H, Schmitt G, Kohn D, Cucchiarini M: SOX9 gene transfer via safe, stable, replication-defective recombinant adeno-associated virus vectors as a novel, powerful tool to enhance the chondrogenic potential of human mesenchymal stem cells. Stem Cell Res Ther 2012, 3:22-36.

48. Shi S, Mercer S, Eckert GJ, Trippel SB: Growth factor regulation of growth factor production by multiple gene transfer to chondrocytes. Growth Factors 2013, 31:32-38.

49. Dong Y, Drissi H, Chen M, Chen D, Zuscik MJ, Schwarz EM, O'Keefe RJ: Wnt-mediated regulation of chondrocyte maturation: modulation by TGF-beta. J Cell Biochem 2005, 95:1057-1068.

50. Tchetina EV, Antoniou J, Tanzer M, Zukor DJ, Poole AR: Transforming growth factor-beta2 suppresses collagen cleavage in cultured human osteoarthritic cartilage, reduces expression of genes associated with chondrocyte hypertrophy and degradation, and increases prostaglandin E(2) production. Am J Pathol 2006, 168:131-140.

51. Gunther M, Haubeck HD, van de Leur E, Blaser J, Bender S, Gutgemann I, Fischer DC, Tschesche H, Greiling H, Heinrich PC, Graeve L: Transforming growth factor beta 1 regulates tissue inhibitor of metalloproteinases-1 expression in differentiated human articular chondrocytes. Arthritis Rheum 1994, 37:395-405.

52. Su S, Grover J, Roughley PJ, DiBattista JA, Martel-Pelletier J, Pelletier JP, Zafarullah M: Expression of the tissue inhibitor of metalloproteinases (TIMP) gene family in normal and osteoarthritic joints. Rheumatol Int 1999, 18:183-191.

53. Shlopov BV, Gumanovskaya ML, Hasty KA: Autocrine regulation of collagenase 3 (matrix metalloproteinase 13) during osteoarthritis. Arthritis Rheum 2000, 43:195-205.

54. Blaney Davidson EN, Remst DF, Vitters EL, Van Beuningen HM, Blom AB, Goumans MJ, van den Berg WB, van der Kraan P: Increase in ALK1/ALK5 ratio as a cause for elevated MMP-13 expression in osteoarthritis in humans and mice. J Immunol 2009, 182:7937-7945.

55. Finnson KW, Parker WL, Ten Dijke P, Thorikay M, Philip A: ALK1 opposes ALK5/Smad3 signaling and expression of extracellular matrix components in human chondrocytes. J Bone Miner Res 2008, 23:896-906.

56. van der Kraan PM, Goumans MJ, Blaney Davidson E, Ten Dijke P: Age-dependent alteration of TGF-beta signalling in osteoarthritis. Cell Tissue Res 2012, 347:257-265.

57. Bakker AC, van de Loo FA, Van Beuningen HM, Sime P, Van Lent PL, van der Kraan PM, Richards CD, van den Berg WB: Overexpression of active TGF-beta-1 in the murine knee joint: evidence for synoviallayer-dependent chondro-osteophyte formation. Osteoarthritis Cartilage 2001, 9:128-136.

58. Blaney Davidson EN, Vitters EL, Van Beuningen HM, van de Loo FA, van den Berg WB, van der Kraan PM: Resemblance of osteophytes in experimental osteoarthritis to transforming growth factor beta-induced osteophytes: limited role of bone morphogenetic protein in early osteoarthritic osteophyte formation. Arthritis Rheum 2007, 56:4065-4073.

59. Blaney Davidson EN, Vitters EL, van den Berg WB, van der Kraan PM: TGF beta-induced cartilage repair is maintained but fibrosis is blocked in the presence of Smad7. Arthritis Res Ther 2006, 8:R65-R72.

60. Mi Z, Ghivizzani SC, Lechman E, Glorioso JC, Evans CH, Robbins PD: Adverse effects of adenovirus-mediated gene transfer of human transforming growth factor beta 1 into rabbit knees. Arthritis Res Ther 2003, 5:R132-R139.

61. Remst DF, Blaney Davidson EN, Vitters EL, Blom AB, Stoop R, Snabel JM, Bank RA, van den Berg WB, van der Kraan PM: Osteoarthritis-related fibrosis is associated with both elevated pyridinoline cross-link formation and lysyl hydroxylase 2b expression. Osteoarthritis Cartilage 2013, 21:157-164.

62. Van Beuningen HM, Glansbeek HL, van der Kraan PM, van den Berg WB: Differential effects of local application of BMP-2 or TGF-beta 1 on both articular cartilage composition and osteophyte formation. Osteoarthritis Cartilage 1998, 6:306-317.

63. Miura Y, Fitzsimmons JS, Commisso CN, Gallay SH, O'Driscoll SW Enhancement of periosteal chondrogenesis in vitro. Dose-response for transforming growth factor-beta 1 (TGF-beta 1). Clin Orthop Relat Res 1994, 301:271-280.

64. Nishimura K, Solchaga LA, Caplan Al, Yoo JU, Goldberg VM, Johnstone B: Chondroprogenitor cells of synovial tissue. Arthritis Rheum 1999, 42:2631-2637

65. Zhen G, Wen C, Jia X, Li Y, Crane JL, Mears SC, Askin FB, Frassica FJ, Chang W, Yao J, Carrino JA, Cosgarea A, Artemov D, Chen Q, Zhao Z, Zhou X, Riley L, Sponseller P, Wan M, Lu WW, Cao X: Inhibition of TGF-beta signaling in mesenchymal stem cells of subchondral bone attenuates osteoarthritis. Nat Med 2013, 19:704-712.

66. Nita I, Ghivizzani SC, Galea-Lauri J, Bandara G, Georgescu HI, Robbins PD, Evans $\mathrm{CH}$ : Direct gene delivery to synovium. An evaluation of potential vectors in vitro and in vivo. Arthritis Rheum 1996, 39:820-828.

67. Noh MJ, Copeland RO, Yi Y, Choi KB, Meschter C, Hwang S, Lim CL, Yip V, Hyun JP, Lee HY, Lee KH: Pre-clinical studies of retrovirally transduced human chondrocytes expressing transforming growth factor-beta-1 (TG-C). Cytotherapy 2010, 12:384-393.

68. Ha CW, Noh MJ, Choi KB, Lee KH: Initial phase I safety of retrovirally transduced human chondrocytes expressing transforming growth 
factor-beta-1 in degenerative arthritis patients. Cytotherapy 2012, 14:247-256.

69. Scharstuhl A, Vitters EL, van der Kraan PM, van den Berg WB: Reduction of osteophyte formation and synovial thickening by adenoviral

overexpression of transforming growth factor beta/bone morphogenetic protein inhibitors during experimental osteoarthritis. Arthritis Rheum 2003, 48:3442-3451.

doi:10.1186/1479-5876-11-211

Cite this article as: Venkatesan et al:: rAAV-mediated overexpression of

TGF- $\beta$ stably restructures human osteoarthritic articular cartilage in situ. Journal of Translational Medicine 2013 11:211.

\section{Submit your next manuscript to BioMed Central and take full advantage of:}

- Convenient online submission

- Thorough peer review

- No space constraints or color figure charges

- Immediate publication on acceptance

- Inclusion in PubMed, CAS, Scopus and Google Scholar

- Research which is freely available for redistribution 